\title{
Which factors most challenged instructors' integration of technology in KSA education between 2009 and 2019? A systematic analysis review
}

\author{
Omran Alharbi \\ Glasgow university, Glasgow, UK
}

\author{
Abdulrahman M. Alshabeb \\ Department of English, College of Languages and Translation \\ Yousef Alshammari \\ University of Glasgow, Glasgow, UK \\ Riam K. Almaqrn \\ Faculty of Education \\ Majmah University, Majmah, Saudi Arabia
}

Al Imam Mohammed Ibn Saud Islamic University, Riyadh, Saudi Arabia.

\begin{abstract}
The introduction of technologies such as E-learning, Learning Management System (LMS), Twitter, Facebook etc. into teaching and learning practices can make the education environment more attractive and active. However, there are some impediments, both external and internal, that influence the use of this technology. As a result, this study attempts to review and analyse studies that have investigated the important internal and external obstacles to faculty members' use of technology in Saudi education. This study is a systematic analysis review of the relevant literature published between 2009 and 2019. The methodology adopted was the searching of databases. Many databases were searched in order to find the largest number possible of resources and references. Following the criteria established for collecting this data, 16 studies were finally included in the review. The results indicate that a lack of interests and knowledge, and attitudes are the most common internal elements that affect instructors' use of technology in the Saudi education context, whereas lack of training and time were mentioned as the most common elements that affect instructors use of technology in Saudi education by previous research. This paper discusses the review findings and makes some recommendations.
\end{abstract}

Keywords: Factors, Education, KSA, LMS, E-Learning, Technology, Challenges.

\section{INTRODUCTION}

The adoption of new technology in the teaching and learning process is inevitable due to its numerous advantages. These include the fact that technology makes information available any time, it is quick to obtain information, it saves time and allows instructors and learners to contact each other anytime and anywhere. According to Arkorful and Abaidoo (2015), technology allows people to easily access a huge amount of information. In addition, the use of E-learning in education helps those learners who find it difficult to attend lessons in the classroom. Institutions and organisations around the world have made efforts to adopt technology in their daily practices, especially in education, in order to provide an effective learning and teaching environment. For example, the Ministry of Education in Saudi Arabia has 
spent heavily on introducing technology into education, and it has encouraged its use among Saudi universities and schools.

Despite the effort made by the Saudi government, the level of use of technology in education is still low (Alharbi and Alotebi, 2019). According to Alharbi and Alotebi (2019), this may be due to a variety of challenges that affect educators and faculty members' use of technology in an educational setting. These difficulties include a lack of skills, training, institutional support, technical support, knowledge and interest, and negative attitudes towards the use of technology (Alharbi and Lally, 2017). As a result, this study aims to examine in depth the factors that influence faculty members' use of technology in their teaching. Specifically, this study will review and analyse the internal and external factors (lack of knowledge and interest, and negative attitudes) that have been indicated by previous research in order to gain a comprehensive understanding of these issues. This study starts with the introduction and it then presents the goal of this study and the research question. It reviews the literature on the internal and external issues regarding the use of technology in Saudi Arabian education in general. The methodology and ethics are discussed before the findings and discussion sections are presented. Finally, this paper draws the conclusions, makes recommendations and suggests future work in this area.

\section{The purpose of the study}

This study aims to examine the internal and external issues that delayed the use of the Learning Management System (LMS) in Saudi Arabian universities from 2009 and 2019, in order to see to what extent these factors affected faculty members' use of the LMS.

\section{Research question}

The research question that underpins this study is: what were the internal and external obstacles associated with the adoption of the LMS in universities in Saudi Arabia from 2009 to 2019 ?

\section{METHODOLOGY}

This paper has been carried out adopting the method of a systematic review. First of all, the selection criteria for both inclusion and exclusion were established. This process was guided by the aim of the research, which was to identify the internal and external difficulties that delay faculty members' use of E-learning tools and their associated technology in their teaching activities. The selection criteria implemented in this paper by the researchers are given in Table 1. The publications referred to were issued between 2009 and 2019; these were combined with unpublished debates and dissertations. Several sources were searched for the relevant literature: Google Scholar, Glasgow University Library, Saudi Digital Library and Scopes.

Following the application of the inclusion and exclusion criteria, 16 studies were found to be suitable for this review and they are shown in Table 2. 
Alharbi, O., Alshabeb, A. M., Alshammari, Y., \& Almaqrn, R. K. (2019). Which factors most challenged instructors' integration of technology in KSA education between 2009 and 2019? A systematic analysis review. Advances in Social Sciences Research Journal, 6(12) 198-205.

Table 1: Selection criteria

\begin{tabular}{lll}
\hline Factor & Inclusion criteria & Exclusion criteria \\
\hline Language & Arabic and English & Other \\
\hline Publication date & $2009-2019$ & Published prior to \\
& & 2009 \\
\hline Search in & Theses (either PhD or Master's) articles, journals, books & 'Grey' literature \\
\hline $\begin{array}{l}\text { Conditions of } \\
\text { interest }\end{array}$ & $\begin{array}{l}\text { Research carried out to explore the internal and external issues } \\
\text { affecting instructors' usage of LMS in Saudi Arabia }\end{array}$ & - \\
\hline $\begin{array}{l}\text { Geographical } \\
\text { coverage }\end{array}$ & Saudi Arabia & - \\
\hline Study design & Any design & - \\
\hline Study methods & Any approaches & \\
\hline
\end{tabular}


Table 2: Resources used in this research

\begin{tabular}{|c|c|c|c|}
\hline Title of research & Study sample & $\begin{array}{l}\text { Place } \\
\text { conducted }\end{array}$ & Author and year \\
\hline $\begin{array}{l}\text { Teacher's Attitudes towards } \\
\text { Integrating Technology: Case } \\
\text { Studies in Saudi Arabia and the } \\
\text { United States }\end{array}$ & Teachers & $\begin{array}{l}\text { Saudi } \\
\text { Arabia }\end{array}$ & Alharbi, 2013 \\
\hline $\begin{array}{l}\text { Academics' Adoption and Usage } \\
\text { of Learning Management } \\
\text { Systems in Saudi Arabia's } \\
\text { Universities }\end{array}$ & $\begin{array}{l}\text { Teachers, students, leaders of E- } \\
\text { learning }\end{array}$ & $\begin{array}{l}\text { Saudi } \\
\text { Arabia }\end{array}$ & Alshammri, 2015 \\
\hline $\begin{array}{l}\text { Towards Successful } \\
\text { Implementation of ICT in Saudi } \\
\text { Schools (Literature Review) }\end{array}$ & Literature Review & $\begin{array}{l}\text { Saudi } \\
\text { Arabia }\end{array}$ & $\begin{array}{l}\text { Albugami and Ahmed, } \\
2015\end{array}$ \\
\hline $\begin{array}{l}\text { Obstacles to Technology Use } \\
\text { When Addressing Saudi Primary } \\
\text { Students' } \\
\text { Mathematics Difficulties }\end{array}$ & $\begin{array}{l}\text { Six teachers with semi-structured } \\
\text { interview tool }\end{array}$ & $\begin{array}{l}\text { Saudi } \\
\text { Arabia }\end{array}$ & $\begin{array}{l}\text { Mansour and Higgins, } \\
2016\end{array}$ \\
\hline $\begin{array}{l}\text { Towards Successful } \\
\text { Implementation of ICT In } \\
\text { Education }\end{array}$ & Review of literature & $\begin{array}{l}\text { Saudi } \\
\text { Arabia }\end{array}$ & Alharbi, 2014 \\
\hline $\begin{array}{l}\text { Adoption of E-learning in Saudi } \\
\text { Arabian University education: } \\
\text { Three factors affecting education }\end{array}$ & Review of literature & $\begin{array}{l}\text { Saudi } \\
\text { Arabia }\end{array}$ & Alharbi and Lally, 2017 \\
\hline $\begin{array}{l}\text { Education Policy in Saudi Arabia } \\
\text { and its Relation to Secondary }\end{array}$ & $\begin{array}{l}\text { Instructors, head instructors and } \\
\text { ICT coordinators }\end{array}$ & $\begin{array}{l}\text { Saudi } \\
\text { Arabia }\end{array}$ & Oyaid, 2009 \\
\hline
\end{tabular}

School Teachers' ICT Use,

Arabia

Perceptions, and Views of the

Future of ICT in Education

Implementation of ICT Policy in Secondary Schools in Saudi Arabia
Teachers (45). Interviews were conducted with the Head of ICT in the Ministry of Education, Managers of ICT in three districts, and Principals of selected schools in the three regions.

\section{Influential Factors and Faculty}

Members' Practices in

Technology Integration Using

ISTE Standards for Teacher

Preparation at Taibah

University- Saudi Arabia
Perceived Barriers owards eLearning by Faculty Members at

a Recently Established

University in Saudi Arabia

\section{Saudi \\ Al Mofarreh, 2016}

Arabia

Saudi

Arabia Bajabaa,2017

\section{Teachers}

$\begin{array}{lll}214 \text { Teachers } & \text { Saudi } & \text { Al Gamdi and Samarji, } \\ & \text { Arabia } & 2017\end{array}$

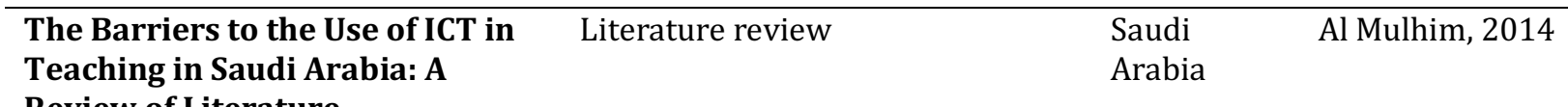

Review of Literature

\begin{tabular}{llll}
\hline Faculty Members' Perceptions & Questionnaires with 174 teachers & Saudi & Ibrahim, Mohamed, \\
towards Utilizing & & Arabia & Aldhafeeri, Alqdah, \\
Blackboard in Teaching System & & 2019 \\
at Hafr Al-Batin & & \\
University, Saudi Arabia & & \\
\hline
\end{tabular}


Alharbi, O., Alshabeb, A. M., Alshammari, Y., \& Almaqrn, R. K. (2019). Which factors most challenged instructors' integration of technology in KSA education between 2009 and 2019? A systematic analysis review. Advances in Social Sciences Research Journal, 6(12) 198-205.

\begin{tabular}{|c|c|c|c|}
\hline $\begin{array}{l}\text { How Do Teachers and Students } \\
\text { Perceive the Utility of } \\
\text { Blackboard as a Distance } \\
\text { Learning Platform? (Case Study } \\
\text { from Taibah University, Saudi } \\
\text { Arabia) }\end{array}$ & $\begin{array}{l}\text { Students and teachers at Taiba } \\
\text { University, questionnaire and } \\
\text { interviews }\end{array}$ & $\begin{array}{l}\text { Saudi } \\
\text { Arabia }\end{array}$ & Alaofi, 2016 \\
\hline $\begin{array}{l}\text { Perceptions of Blended Learning } \\
\text { in Saudi Universities }\end{array}$ & $\begin{array}{l}\text { Students and lecturers, qualitative } \\
\text { study }\end{array}$ & $\begin{array}{l}\text { Saudi } \\
\text { Arabia }\end{array}$ & Alebaikan, 2010 \\
\hline
\end{tabular}

\begin{tabular}{llll}
\hline Faculty Members' Perception of & Educators, open-ended & Saudi & Alenezi, 2012 \\
E-learning in Higher Education & questionnaire & Arabia &
\end{tabular}
in the Kingdom of Saudi Arabia (KSA)

\begin{tabular}{llll}
\hline $\begin{array}{l}\text { Attitudes of Saudi Universities } \\
\text { Faculty Members towards Using } \\
\text { Learning Management System } \\
\text { (JUSUR) }\end{array}$ & $\begin{array}{l}90 \text { Faculty members, } \\
\text { questionnaire }\end{array}$ & $\begin{array}{l}\text { Saudi } \\
\text { Arabia }\end{array}$ & Hussein, 2011 \\
\end{tabular}

\section{Ethics}

This study is a systematic review analysis, which means that the data were obtained from available databases and resources, so there is no requirement for the researcher to seek ethical approval.

\section{FINDINGS AND DISCUSSION}

In this section, the results from the studies will be discussed and presented. This study aims to present the internal and external issues that delayed the use of the LMS in Saudi Arabian Universities from 2009 to 2019 in order to see to what extent these factors affected faculty members' use of the LMS. As already mentioned, 16 studies were included in this review.

Oyaid (2009) reported that teachers' use of the LMS was constrained by time, inadequate training and financial problems. In 2010, Alebaikan's study indicated that poor internet services, students' and teachers' lack of IT skills, a lack of internet labs, resistance to change and pedagogical issues were the primary factors affecting instructors' use of technology, according to the participants. However, these results were extended in 2011 by Hussein when he conducted research with 90 participants who were faculty members from a variety of universities. The results stated that resistance to change, insufficient computer to student ratio, deficiency of administrative support, inadequate awareness among faculty members and a lack of technical support were the main elements that delayed educators' adoption of technology in their teaching methods. In 2012, Alenezi carried out research in two institutions that aimed to investigate educators' perceptions of the use of technology in Saudi universities. This added new factors to those discovered by previous research. These were deficiency of knowledge and deficiency of equipment in classes for the implementation of E-learning tools. Along the same lines, in 2013 Alharbi conducted a case study in KSA and the USA to understand educators' attitudes towards the integration of technology into teaching methods. The results indicated that teachers had negative attitudes towards the use of technology in the education process and that a lack of time was another major factor preventing them from adopting technology in their teaching. However, in 2014 there were two studies published on this topic: one by Alharbi (2014) and the other one by Al Mulhim (2014). These studies were a review of the literature about the challenges to the use of technology in education. The results from these 
studies were that the main barriers were negative attitudes, a lack of knowledge, poor infrastructure, policy, planning, administrative support and skills, a lack of time, a lack of access to IT and a lack of training. These factors reoccurred in 2015 in the findings of a study by Alshammari in three universities; this study also reported a lack of interest. In the same year, Albugami and Ahmed (2015) found that negative attitudes, a lack of IT resources, a lack of ICT policy, a lack of technical support, time limitations, a lack of training and resistance to change were the major factors delaying the employment of new technology in education in Saudi institutions. It appears that the challenges that hindered the use of technology in Saudi education in 2014 and 2015 were almost the same. New factors were added in 2016, such as a lack of English skills and a lack of incentives, in a study conducted by Al Gamdi and Samarji. This study's results also repeated some of the barriers that were found in previous studies, such as a lack of technical support, poor internet services, a lack of hardware and a lack of time. Bajabaa (2017) studied the factors that affected instructors' use of technology at Taiba University. It was found that a lack of training, lack of administrative support and heavy workload were the primary problems that educators encountered when they used the LMS in their teaching. In 2018, there were no studies published in this area, based on our research of the databases. In 2019, research was published by Ibrahim, Mohamed, Aldhafeeri and Alqdah about faculty members' perceptions of utilising Blackboard in the teaching system at Hafr AlBatin University. The researchers indicated that a lack of motivation, time and training were the important factors that prevented educators' use of the Blackboard system at the university. To sum up, after presenting the results it can be said that a lack of training and a lack of time were the major factors that delayed the use of technology by educators in Saudi institutions, as these two factors were indicated by the majority of research conducted between 2009 and 2019. For example, a lack of training was mentioned by ten studies and a lack of time was stated by nine. The factors are presented in more detail in Figure 1.

Figure 1: The factors that affected instructors' use of technology in education in KSA during the period 2009-2019.

\section{The most challenges that affected educators use of technology in Saudi Education during the period from 2009 and 2019.}

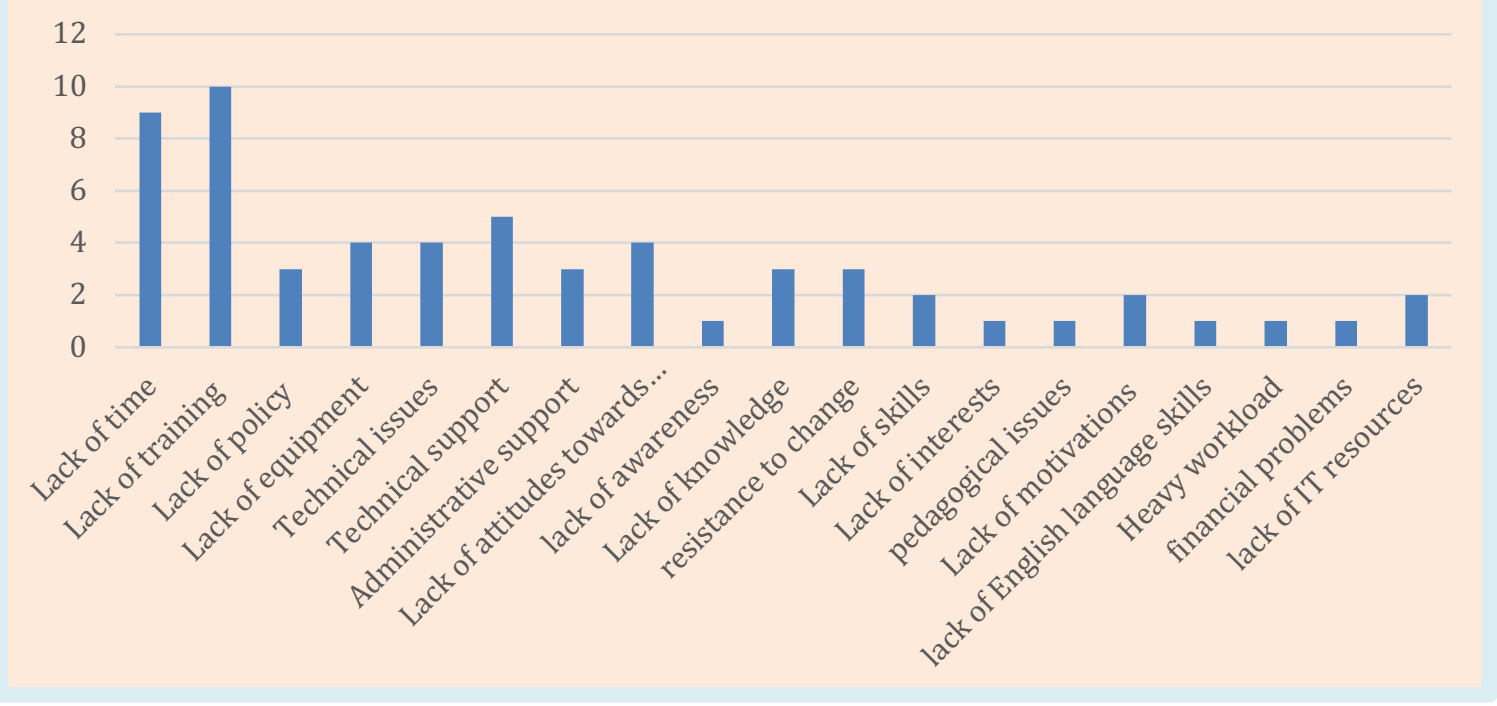

\section{CONCLUSIONS AND RECOMMENDATIONS}

The primary goal of this paper was to investigate the findings of academic literature related to the internal and external elements that delayed instructors' implementation of E-learning tools in education and teaching practices at Saudi institution from 2009 to 2019. After presenting 
the literature review, it could be argued that despite the Saudi government's sustained efforts to assist the country's development of the latest technology such as LMSs in education processes, there are still internal and external difficulties that limit educators' effective utilisation of this capability. These internal and external barriers include a lack of time, training, technical support and administrative support. Therefore, efforts should be made by decision makers in Saudi establishments to solve these problems. Several recommendations can be made, based on the outcomes of this research.

The first recommendation is that educators should find training courses that are suitable for them in terms of the time and content of the workshop. Secondly, teachers' workload should be reduced since this might help them to adopt technology in effective ways in their teaching process. Moreover, institutions should allocate a technical unit to each college to solve any technical problems that educators or students might face. In addition, universities should provide incentives to educators who use E-learning tools in their teaching approaches, as this might encourage them to adopt technology in their daily activities when they teach their students. Finally, a clear policy for the integration and implementation of E-learning strategies should be put in place by universities.

\section{PROPOSAL FOR FUTURE RESEARCH}

Since this study has determined the external and internal barriers to educators' use of technology in Saudi universities, future research might be carried out with decision makers to examine their perceptions of which solutions are most effective in overcoming these barriers to educators' adoption of E-learning tools in their teaching.

\section{References}

Al Gamdi, M.A. and Samarji, A., 2016. Perceived barriers towards e-Learning by faculty members at a recently established university in Saudi Arabia. International Journal of Information and Education Technology, 6(1), p.23

Al Mulhim, E., 2014. The barriers to the use of ICT in teaching in Saudi Arabia: A review of literature. Universal Journal of Educational Research, 2(6), pp.487-493

Alabdulaziz, M. and Higgins, S., 2016. Obstacles to technology use when addressing Saudi primary students' mathematics difficulties. International Journal of Engineering Research and Technology, 5(10), pp.412-417

Alaofi, S., 2016. How do teachers and students perceive the utility of blackboard as a distance learning platform? (case study from Taibah university, Saudi Arabia). Doctoral Dissertation

Albugami, S.S. and Ahmed, V., 2015. Towards successful implementation of ICT in Saudi schools (literature review)

Alebaikan, R.A., 2010. Perceptions of blended learning in Saudi universities. Doctoral Dissertation

Alenezi, A., 2012. Faculty members' perception of e-learning in higher education in the Kingdom of Saudi Arabia (KSA) (Doctoral dissertation).

Alharbi, A.M., 2013. Teacher's attitudes towards integrating technology: Case studies in Saudi Arabia and the United States

Al-Harbi, H., 2014. Towards successful implementation of ICT in education. In The 2014 WEI International Academic Conference Proceedings (pp. 33-46)

Alharbi, O. and Alotebi, H., 2019. External issues affecting teachers' use of technology in Saudi Arabia: Systematic literature review. Advances in Social Sciences Research Journal, 6(1).

Alharbi, O. and Lally, V., 2017. Adoption of E-Learning in Saudi Arabian university education: Three factors affecting educators. European Journal of Open Education and E-learning Studies

Al-Shammari, M. O., \& Higgins, S. 2015. Obstacles facing faculty members in the effective implementation of elearning at some universities in Saudi Arabia. International Journal of Information Technology \& Computer Science $19(1), 1-12$. 
Arkorful, V. and Abaidoo, N., 2015. The role of e-learning, advantages and disadvantages of its adoption in higher education. International Journal of Instructional Technology and Distance Learning, 12(1), pp.29-42

Bajabaa, A.S., 2017. Influential factors and faculty members' practices in technology integration using ISTE standards for teacher preparation at Taibah University-Saudi Arabia (Doctoral dissertation, Kansas State University)

Hussein, H.B., 2011. Attitudes of Saudi universities faculty members towards using learning management system (JUSUR). Turkish Online Journal of Educational Technology-TOJET, 10(2), pp.43-53

Ibrahim, L. Mohamed, A. Aldhafeeri, F. and Alqdah, M., 2019. Faculty members' perceptions towards utilizing blackboard in teaching system at Hafr Al-Batin University, Saudi Arabia. Journal of Nursing Education and Practice 9(5), pp 64-76.

Mofarreh, A. and Ibrahim, Y., 2016. Implementation of ICT policy in secondary schools in Saudi Arabia. (Doctoral dissertation)

Oyaid, A., 2009. Education policy in Saudi Arabia and its relation to secondary school teachers' ICT use, perceptions, and views of the future of ICT in education. (Doctoral dissertation) 